\title{
Medical Waste Disposal Regulation in International Laws
}

\author{
${ }^{1}$ Kamil M. Arslanov, ${ }^{2}$ Arthur I. Khabirov, ${ }^{3}$ Gulnara M. Khamitova \\ ${ }^{1-2}$ Kazan Federal University \\ ${ }^{3}$ Kazan State Medical University \\ Email: art.khabir@gmail.com
}

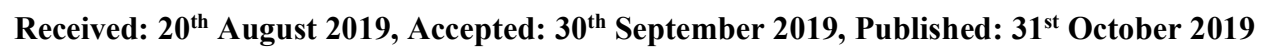

\begin{abstract}
The article discusses international and national experience in the legal regulation of medical waste disposal. Particular attention is paid to foreign experience and the possibility of legislation application and improvement on the disposal of medical waste in the Russian Federation. The development of medicine is currently characterized by a dynamic increase of medical waste volume. In this regard, the search is underway for new disposal and destruction technologies, as well as principles for medical waste management, the issues of activity legal regulation for the treatment of such waste are being discussed [1].

About 16 billion injections are given worldwide every year, but subsequently not all needles and syringes are properly disposed. Open burning and incineration of medical waste can, under certain circumstances, result in the release of dioxins, furans and solid particles.

In collaboration with other partners, WHO has also developed a series of training modules on good practices in medical waste management covering all aspects of waste management activities, from waste identification and classification to the proposals that define their safe disposal, not related to incineration.
\end{abstract}

\section{Keywords}

Medical Waste, Waste Removal, Waste Management, Legal Regulation, Basel Convention, Stockholm Convention

\section{Introduction}

Unutilized medical waste poses a serious threat to the environment. Much attention is paid abroad to the collection, disposal and recycling of medical waste. The process of safe disposal of this type of hazardous waste has long been established in European countries.

In Russia, unfortunately, the situation with the waste of medical institutions is worse. The reason for this is the imperfect legislation of our country.

It should be noted that the issues of medical waste management in Russian national legislation began to be regulated quite recently, the legislation in this area is still developing, which confirms the relevance of this study.

According to the World Health Organization, of the total amount of waste generated as the result of health activities, about $85 \%$ are ordinary non-hazardous waste. The remaining $15 \%$ are considered hazardous materials, which may be infectious, toxic or radioactive. The measures providing safe and environmentally sound management of health care waste can prevent the adverse effects of such waste on health and the environment, including the unintentional release of chemical or biological hazards, including drug-resistant microorganisms, into the environment, thereby protecting the health of patients, population and the public [2].

International law includes the following agreements regarding the international transport and disposal of hazardous waste:

- Convention on Civil Liability for Damage Caused by the Transport of Dangerous Goods by Road, Rail and Inland Water Transport (CRTD), Geneva, 1989.

- Convention on Control of Transboundary Movements of Hazardous Wastes and their Disposal, Basel, 1989

- Convention on the Prohibition of Import into Africa and the Control of Transboundary Movements and the Regulation of Hazardous Wastes in Africa, Bamako, 1991

- Convention on Prior Informed Consent Procedure for Certain Hazardous Chemicals and Pesticides in International Trade, Rotterdam, 1998

- Convention on the Transboundary Effects of Industrial Accidents, Helsinki, 1992

- European Agreement concerning the International Carriage of Dangerous Goods by Inland Waterways (I), Geneva, 2000

- European Agreement concerning the International Carriage of Dangerous Goods by Road (ADR), Geneva, 1957

- FAO International Code of Conduct for the Distribution and Use of Pesticides, Rome, 1985

- Minamata Convention on Mercury, Minamata, 2013

- Stockholm Convention on Persistent Organic Pollutants Stockholm, 2001

- Convention on the Prohibition of Import into the Island Countries of Hazardous and Radioactive Waste Forum and on the Control of Transboundary Movements and the Treatment of Hazardous Wastes in the South Pacific Region, Vaigani, 1995 [2]. 


\section{Methods}

The study is based on the method of current Russian legislation and law enforcement practice and existing European (world) standard analysis for the purpose of legal unification [3, 386]. The methods of legal modeling and prediction make it possible to determine the need to amend existing Russian regulations, as well as the need to adjust judicial practice [4]. Thanks to the use of modeling and forecasting methods, the consequences of such changes and adjustments can be determined with a sufficient degree of certainty, and it will also be revealed how, ultimately, Russian law enforcement practice will be close to existing European (world) standards [5, 421]. The sociological method allows the assessment of social problems from a legal position, from the perspective of a legislator and law enforcer $[6,651]$. The interpretation method complements the comparative legal analysis in the study, that allows you to understand and compare Russian and European (world) legal standards [7, 62]. The use of various methods allowed us to formulate the main theoretical conclusions and make our own proposals on the studied sphere of public relations $[8,70]$.

\section{Results and Discussion}

The experience of foreign countries on the legal regulation of medical waste disposal is interesting. So in 2012, the United States spent up to $\$ 2.5$ billion on the proper disposal of medical waste [9].

According to the EPA (Environmental Protection Agency, USA), the definition of medical waste is quite broad: "all waste generated in medical facilities, such as hospitals, clinics, doctors' offices, dental offices, blood banks and veterinary hospitals / clinics, as well as medical research institutions and laboratories."

In addition to laws implementing or promoting the parts of US laws, some US states have prominent laws on other waste and the environment. For example, in the state of Massachusetts, medical waste regulations are administered by the state Department of Public Health and local health councils. The Department of Public Health is guided by the State Sanitary Code, the part of which regulates the storage, treatment and disposal of medical waste [10].

Also one can include environmental laws in this list that indirectly affect the treatment or disposal of medical waste: - The European Union (EU) legislation on waste includes (for example, the Regulation (EU) No 1013/2006 of the European Parliament and of the Council (14 June 2006) on waste transport; the Decision 2000/532/EU establishing the list of wastes, etc.);

- European Union legislation on waste management operations (e.g. the Directive 2000/76/EU of the European Parliament and of the Council on 4 December 2000 about waste incineration; Council Directive 1999/31/EU (April 26, 1999) on waste disposal) [11].

The legislation on waste management in New Zealand (the Law on minimization of waste of 2008; the Law on local self-government of 2002, etc.) is also of interest [12].

The simple discharge of mixed wastes is practiced almost everywhere, and especially in developing countries, since they cannot mobilize financial resources for the application of expensive technologies. Waste management remains a linear collection and disposal system that poses a risk to health and the environment. For example, India is already facing a serious waste disposal problem [13].

In India, urban local governments, commonly known as municipal corporations, are responsible for health-related activity management. The Department of Public Health is responsible for sanitation, street cleaning, epidemiological surveillance and food falsification. Key issues in India include lack of waste collection and separation, lack of land, e-waste dumping, lack of awareness, etc.

With the ratification of the Basel Convention on the Control of Transboundary Movements of Hazardous Wastes and their Disposal by the Russian Federation in 1994 in accordance with Federal Law (25.11.1994) N 49-FL "On Ratification of the Basel Convention about the Control of Transboundary Movements of Hazardous Wastes and their Disposal", the Russian Federation adopted the obligation to form a set of norms in the national legislation relating, inter alia, to medical waste [14]. Since that time, the development of the necessary regulatory acts has begun.

The official beginning of the medical waste problem legislative solution in Russia is 1999, when SanPiN "Rules for the collection, storage and disposal of waste from medical and preventive institutions" 2.1.7.728-99 was first developed and introduced into healthcare practice, and the implementation of the measures recommended by them made it possible to improve medical waste management situation [15]. However, these Rules have not decided some aspects of the safe waste management of medical institutions, as they are not provided with any regulatory acts. The main reason for this is the lack of clear terminology, classification and composition of medical waste.

With the adoption of the Federal Law "On the Basics of Citizen Health Protection in the Russian Federation" in 2011, the definition of the term "medical waste" was first enshrined legislatively. According to the Art. 49 of the Federal Law "On the Basics of Citizen Health Protection in the Russian Federation", all types of waste are medical, including anatomical, pathoanatomical, biochemical, microbiological and physiological, generated in the process of carrying out medical activities and pharmaceutical activities, the activities for the production of medicines and medical products [16]. 
The criteria for medical waste classification as a particular class are enshrined in the Decree of the Russian Federation Government No. 681 "On the Approval of the Criteria for Medical Waste Division into Classes by the Level of Their Epidemiological, Toxicological, Radiation Hazard, and Negative Impact on the Environment” dated on July 4, 2012 [17].

The procedure for accounting, storage, transmission and transportation of microorganisms of pathogenicity groups I - IV is established in SP 1.2.036-95. 1.2. Epidemiology [18].

\section{Conclusions}

Medical waste in most countries is classified as hazardous waste, however, as follows from the above classification adopted in the Russian Federation, medical waste can be non-hazardous [19].

$75-90 \%$ of the waste generated in the health care system does not belong to risk group waste or is "ordinary" health care waste that is comparable to household waste.

As shown in table 1, there are significant differences in legislation, not only in terms of contract conclusion for the disposal of medical waste, but also in the field of control.

\begin{tabular}{|l|l|l|}
\hline \multicolumn{1}{|c|}{ Foreign experience } & \multicolumn{1}{c|}{ Russian experience } & \multicolumn{1}{c|}{ Proposals } \\
\hline $\begin{array}{l}\text { Medical waste concept is } \\
\text { missing. }\end{array}$ & $\begin{array}{l}\text { There is no concept of "disposal", } \\
\text { and "waste disposal". }\end{array}$ & $\begin{array}{l}\text { The need to introduce a list of medical } \\
\text { waste to be disposed of. }\end{array}$ \\
\hline $\begin{array}{l}\text { Waste management } \\
\text { agreement is concluded only } \\
\text { with the state. }\end{array}$ & $\begin{array}{l}\text { Enterprises make decisions on } \\
\text { waste disposal independently. }\end{array}$ & $\begin{array}{l}\text { To develop standards for the generation } \\
\text { of medical waste, taking into account the } \\
\text { specifics of a medical institution. }\end{array}$ \\
\hline $\begin{array}{l}\text { Medical waste management } \\
\text { is controlled by federal } \\
\text { environmental agencies. }\end{array}$ & $\begin{array}{l}\text { Control over the disposal of } \\
\text { medical waste is performed by } \\
\text { local governments. }\end{array}$ & $\begin{array}{l}\text { To develop an administrative regulatory } \\
\text { system in the medical institution. }\end{array}$ \\
\hline
\end{tabular}

Table 1: Foreign and Russian Experience of Medical Waste Disposal Market State Regulation

It is worth noting that recently environmental authorities have tightened the requirements for the collection and disposal of medical waste. For this reason, a large number of medical institutions have come to the conclusion that it is necessary to perform the inventory of the waste generated as a result of their activities. As a rule, medical institutions keep records of devices that contain mercury or radiation components. Medical waste must be removed by specialized companies, which must be disposed of after collection.

The rules and norms for the treatment of medical waste in hospitals and other medical institutions prescribe used dressings after they are treated with disinfectants and disposed of with ordinary household waste and to a landfill. And this, despite the fact that chlorine preparations are usually used as disinfectants.

In addition, waste from operations is a big problem. Such waste is disposed of in special furnaces or must be buried. However, most of the furnaces in which such waste is incinerated does not meet sanitary standards at all, since they were built in the absence of design documentation, and the method of medical waste disposal in them does not make it possible to ensure the required temperature.

The problem of hospital waste disposal is of epidemiological and environmental nature due to the polymorphism of this type of waste and the relevance of potential hazard factors in contact with them, such as toxicity, radioactivity and infectivity. For this reason, the organization of a hospital waste management system in medical institutions (MI) involves the consideration of the requirements of not only sanitary, but also environmental legislation. However, despite the legal foundations and the active interest of the environmental prosecutor's office concerning this trend in health facilities, the Rospotrebnadzor bodies have a specialized document - Sanitary Rules No. 2.1.7.728-99 "Rules for the Collection, Storage and Disposal of Wastes from Treatment and Prevention Institutions," which guide performance of control and penalty functions [20].

\section{Summary}

Thus, it seems appropriate to study the experience of developed countries, in particular the United States and European countries, regarding the legal regulation of medical waste disposal, since the problem of the safe management of medical waste is important for each subject of the Russian Federation. In particular, US law deserves attention, namely the laws on the tracking of medical waste and on national environmental policies.

Since we know that the principle of the rule of law lies in the fact that the method of relation regulation is precisely the law, and not the interests of the authorities [21], we therefore consider it is appropriate to develop and implement the State Sanitary Code, which would regulate the storage, processing and disposal of medical waste. New Zealand law, in particular the laws on resource management and hazardous substances and new organisms, regulates the disposal of waste, including hazardous waste. According to the experience of India, it is possible to create a National Solid Waste Association, which would be responsible for the disposal of toxic and hazardous waste, including biomedical waste. 


\section{Acknowledgements}

The work is performed according to the Russian Government Program of Competitive Growth of Kazan Federal University.

\section{References}

[1]. Orlov A.Yu. Justification of the sanitary and chemical hazard of medical waste: the dissertation by $\mathrm{PhD}$ in Medicine: 02.14.01. Moscow, 2010.

[2]. Healthcare waste. URL.: http://www.who.int/news-room/fact-sheets/detail/health-care-waste (reference date: 08.03.2019)

[3]. Comparative Law. An Introduction to the Comparative Method of Legal Study and Research. By Gutteridge H. C., K.C., LL.D. (Cambridge Studies in International and Comparative Law, Vol. I.) - London: Cambridge University Press. The Cambridge Law Journal. - 1947. - 9(3). - pp. 386 - 387.

[4]. Dale, William. Legislative Drafting: A New Approach: Comparative Study of Methods in France, Germany, Sweden and the United Kingdom. - London: Butterworths, 1977. - 341 p.

[5]. Artur I. Khabirov, Gulnara M. Khamitova. On The Issue of the Place of a Loan Commitment in the System of the Russian Law of Obligations // The Journal of Social Sciences Research. -2018. - Special Issue - 5. - pp. 421424.

[6]. Siems, M., \& Mac Síthigh, D. Mapping legal research. The Cambridge Law Journal. - 2012. - 71(3). - pp. 651 676.

[7]. Davies, P. Rectification versus interpretation: the nature and scope of the equitable jurisdiction. - The Cambridge Law Journal. - 2016. - 75(1). - pp. 62-85.

[8]. Khabirov Artur. On the issue of the consensual construction of a loan agreement // National Academy of Managerial Staff of Culture and Arts Herald. - 2018. - № 3. - pp. 70-73.

[9]. Medical Waste Regulations. URL.: https://www.malsparo.com/ regulations.htm

[10]. Medical Waste Disposal. URL.: https://nationalbiocare.com/new-orleans-medical-waste-disposal.php

[11]. EU Waste Legislation URL.: http://ec.europa.eu/ environment/waste/legislation/index.htm

[12]. Legal framework for waste. URL.: / http:/www.mfe.govt.nz/waste/waste-strategy-and-legislation/legalframework-waste

[13]. R. Agarval, M. Chaudhary, D. Singh. Waste Management Initiatives in India // European Journal of Science. 2015. - No. 6. - pp. 105-116.

[14]. Federal Law of November 25, 1994 N 49-FL "On Ratification of the Basel Convention about the Control of Transboundary Movements of Hazardous Wastes and their Disposal”. URL.: http://base.garant.ru/2108511/

[15]. SanPiN 2.1.7.728-99 "Rules for the collection, storage and disposal of waste from medical institutions." URL.: https://files.stroyinf.ru/Data1/7/7929/

[16]. The Federal Law of November 21, 2011 N 323-FL "On the Basics of Citizen Health Protection in the Russian Federation". URL.: http://base.garant.ru/ 57499516/

[17]. The decree of the RF Government dated on 04.07.2012, No. 681 "On the approval of the criteria for medical waste division into classes according to the degree of their epidemiological, toxicological, radiation hazard, as well as their negative impact on the environment”. URL.: http://base.garant.ru/70197546/

[18]. SanPiN 1.2.036-95. 1.2. Epidemiology. The order of accounting, storage, transmission and transportation of microorganisms of I - IV pathogenicity groups. Sanitary Rules" M., Information and Publishing Center of the State Committee for Sanitary and Epidemiological Supervision of the Russian Federation, 1996. URL.: http://docs.cntd.ru/document/901799960

[19]. N.K. Efimova. Wastes of medical institutions as the factor of medical and environmental risk // The issues of medical care examination and quality. - 2011. - No. 4.

[20]. Sanitary rules No. 2.1.7.728-99. "Rules for the collection, storage and disposal of waste from medical institutions" (as amended on March 16, 2009). URL.: https://files.stroyinf.ru/Data1/7/7929/

[21]. Khamitova G.M. Some aspects of the legal regulation of medical secrets in the Russian Federation // Kazan

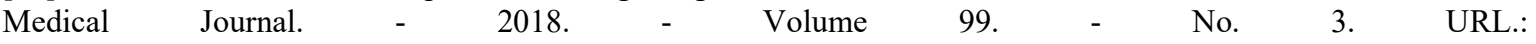
https://elibrary.ru/download/elibrary_34924247_95624368.pdf 